UDC 311.21:338.1(1-04)-047.36

JEL Classification: C18, 047

Doi: 10.31767/su.1(80).2018.01.08

O. M. Motuzka,

PhD in Economics,

Associate Professor of Department for Management of Foreign Economic Activities,

E-mail: lemot@i.ua;

V. V. Parkhomenko,

$P h D$ in Economics), Associate Professor,

Associate Professor of Department for Economics and Business,

E-mail: pviktoria@ukr.net;

National Academy of Statistics, Accounting and Audit

\title{
The Socio-Economic Development of Cross-Border Territories: Statistical Monitoring
}

Because the methodology for studying the socio-economic development of cross-border territories is still poorly developed in the Ukrainian science, this study aims to highlight its theoretical essence and justify the need for statistical monitoring and identification of practical problems related with its applications at personal, institutional and regional level.

Given the global market competition, the socio-economic development of cross-border territories is impossible without creating favorable financial, institutional and infrastructure environment. The socioeconomic development of cross-border territories is determined by a set of indicators reflecting the capabilities of territories located on both sides of the border to produce a certain output of goods and services using the available human and material resources.

The importance of cross-border statistics grows with the expansion of cross-border cooperation. Crossborder statistics refers to the generalized information on the socio-economic development of cross-border territories; it has to support the CBC-related operation of central and local administration bodies and private entities in border regions, aimed at expanding business partnerships and meeting public needs on border territories.

The source of data for cross-border statistics is the statistics of border regions. The analysis shows that trial decisions used now in the Ukrainian statistics system for testing border region statistics, such as statistics of tourism, including travels abroad, are not capable to meet information needs of the regional development policy, foreign trade statistics and statistics of internal and external migration.

The statistics of cross-border regions has to face the following challenges: improve the comparability of statistical indicators by harmonizing statistical surveys' methodology, terminology, definitions and classifications; expand and improve printing and publishing activities; develop analytical work; introduce and develop cross-border surveys; construct on-line cross-border database.

Key words: socio-economic development, mobility, monitoring, cross-border cooperation, cross-border territories, neighboring countries.

The contemporary society is becoming the increasingly more globalized, with its peculiar features more pronounced. They include spatial mobility reflecting the readiness of populations and supreme institutional entities for purposeful change of locations in the preset coordinates of space and time. The large-scale spatial mobility often takes form of tourism or migration. The spatial mobility can have various territorial and time dimensions. Its scale largely depends on the proximity to state border. This type of mobility can be defined as cross-border one.

As the methodology for studies of the socioeconomic development in cross-border territories is still poorly developed in Ukraine, this study aims to highlight its theoretical essence and justify the need for statistical monitoring and identification of practical problems related with cross-border movement at personal, institutional and regional level. It should be noted that a cross-border movement (of people, goods and services) has an impact on the local development and living conditions of residents of border areas, on the one hand, and macroeconomic effects, on the other. Issues of crossborder cooperation have been addressed by foreign and Ukrainian researchers: I. Artiomova, A. Balyan, Z. Broide, I. Bielienkyi, V. Budkin, B. Burkinskyi, V. Chuzhykov, M. Dolishnii, S. Hakman, Ye. Kish, M. Kozoriz, M. Lendel, N. Lankashyn, P. Lankashyn, V. Liashenko, Yu. Makohon, M. Malchka, A. Melnik, N. Mikula, V. Millovda, A. Mokii, I. Mykhasiuk, S. Pirozhkov, V. Pyla, S. Pysarenko, O. Vishniakov, V. Yevdokymenko, and others. 
The key directions of socio-economic development of border towns in Ukraine are associated with improvement of life quality of the population, mitigation of social tensions provoked by unemployment and workforce migration, modernization of municipal infrastructures, socioeconomic integration with border territories of neighboring countries (via the mechanisms for creating cross-border metropolitan areals and networks of partner towns). The Ukraine's intentions to integrate in the European Economic Area cannot be implemented without creating the firm background for strengthening of economic security and competitiveness of border towns and elaborating an adequate model as the guideline for the development of the regional socio-economic system, which would conform to the principles and requirements of the regional policy of EU. The European set of stimuli for socio-economic growth of border towns, based on the concepts of sustainable development, "smart city" and inclusive growth, will not be implemented in Ukraine unless the existing mechanisms for crossmunicipal cooperation of border towns and crossborder cooperation are improved and new ones are introduced.

In the conditions of global market competition, the effective socio-economic development of cross-border territories will not be possible unless the favorable financial, institutional and infrastructure environment is created. The socioeconomic development of cross-border territories is determined by a set of indicators measuring the capabilities of border territories located on both sides of the border to produce a certain output of goods and services by utilizing the available human and material resources.

The objective of the study is a statistical monitoring of the phenomena and processes occurring in cross-border territories, aimed to enhance the capacities of the official statistics of Ukraine, and provide information required for constructing the adequate database on border areas and creating the framework for the performance assessment in these areas.

Now, the cross-border cooperation (CBC) constitutes a key component of the EU policy on neighbouring countries, intended to support the sustained development along the external borders of EU, to bridge the gap in living conditions and address joint challenges across these borders. CBC was first recognized in the European Neighbourhood and Partnership Instrument (ENPI) for 2007-2013, and confirmed for 2014-2020 in the European Neighbourhood Instrument (ENI) [1].

$\mathrm{CBC}$ promotes cooperation between EU countries and neighboring countries that have joint land borders or maritime boundaries. The financing can also be envisaged for collaborative programs involving several EU countries and neighboring countries that may be part of the same maritime basin.

The cross-border system of EU is built on the principles of the territorial cooperation model, but adapted to the specifics of the external cooperation of EU. CBC programs are based on the principles of balanced partnership between the engaged countries located on both sides on the border: EU countries and neighboring countries have equal weight in program decisions, and the projects can be funded only if shared by partners on both sides of the border.

The budget of ENI CBC for 2014-2020 remains the same as the budget of ENI CBC for 2007-2013, amounting to 1.052 billion euro. The budget of $\mathrm{CBC}$ is raised from various sources: ENI and contributions of the European Regional Development Fund (ERDF) [1].

CBC covers collaborative actions aimed at creating and expanding economic, social, ecological, cultural and other relations between regional communities and executive power bodies from Ukraine and neighboring countries, in the competence specified in their national laws, including the Law of Ukraine "On Cross-Border Cooperation" [2].

In 1993, Poland and Ukraine ratified the European Framework Convention on CBC, signed by the countries with European Council membership in Madrid in 1980. In 1995, the agreement on cooperation between statisticians of Poland, Belarus and Ukraine was signed in the town of Kazimierz Dolny; in 2013, the agreement on partnership in creating the scientific, information and statistical cross-border cluster "Infostat Ukraine-Poland" was signed in the city of Lviv [3].

The authors believe that the importance of coordinated and collaborative development of Polish-Ukrainian border regions increased after the enlargement of $\mathrm{EU}$ to the Western borders of Ukraine. The expansion of $\mathrm{CBC}$ opens up new opportunities for more intensive economic activities in peripheral areas and for the enhancement of their competitiveness through the effort aiming to combine and mobilize the resource capacities of neighboring areas. The contemporary paradigm of EU regional policy also puts emphasis on the need for guidelines for territorial development of cross-border regions in Europe though creating respective mechanisms, their institutional and financial security [4]. CBC acts as a catalyst of integration processes in Ukraine in view of the convergence of life quality of the residents in cross-border regions with the one in Central European countries, stimulation of free exchange of people and capital; it also helps mobilize local resources and enhance the effectiveness of their use, enables to combine the countries' effort in addressing problems specific to transport operation.

The Ukrainian realities demonstrate that large scales of cross-border mobility of people from border 
regions are caused by circular migrations as a means of economic survival. The following problematic aspects can be outlined from the analysis of the situation in the Carpaty region:

1) the large scales of illegal cross-border migration of local residents, the considerable growth in circular migration;

2) the increasing scopes of transit services supporting movements of illegal migrants, including illegal transportations of foreign citizens across the state border of Ukraine by groups of persons acting in collusion. This is a problem of special importance for Transcarpaty region. Criminal proceedings are regularly opened on this type of crime by the Department of the Security Service of Ukraine. Most part of illegal migrants attempt to go out by crossing Ukrainian-Slovak (nearly 60\%) and UkrainianPolish (20\%) borders;

3) the increasing burden on the social and ecological system of Carpaty. The migrants often become a source of infection decease (AIDS, tuberculosis, malaria etc.);

4) bad infrastructures of the border and border zone, which worsens the protection of rights of foreign citizens and persons without citizenship on the Ukrainian territory.
The main problems faced by labor migrants from Ukraine in border regions are as follows:

- excessive workload and shortage of border crossings;

- socio-economic exclusion of migrants in foreign countries.

The abovementioned gives evidence of the increasing importance of cross-border statistics. Cross-border statistics refers to the generalized information on the socio-economic development of cross-border territories; it has to support the CBCrelated operation of central and local administration bodies and private entities in border regions, aimed at expanding business partnerships and meeting public needs on border territories.

The source of data for cross-border statistics is the statistics of border regions. Main indicators of border territories, such as Lviv region (Ukraine), Subcarpathia and Lublin voivodships (Poland) for 2016 are as follows (Table 1) [3].

The analysis shows that trial decisions used now in the Ukrainian statistics system for testing border region statistics, such as statistics of tourism, including travels abroad, are not capable to meet information needs of the regional development policy, foreign trade statistics and statistics of internal and external migration.

Table 1

General Characteristics of Border Regions in 2016

\begin{tabular}{|c|c|c|}
\hline \multicolumn{3}{|c|}{ Border region } \\
\hline Lviv region & Subcarpathia voivodship & Lublin voivodship \\
\hline \multicolumn{3}{|c|}{ Area, kм2 } \\
\hline 21831 & 17846 & 25122 \\
\hline \multicolumn{3}{|c|}{ Population, thousand persons } \\
\hline 2534,0 & 2127,7 & 2133,3 \\
\hline \multicolumn{3}{|c|}{ Unemployment by International Labour Organization, \% } \\
\hline 7,7 & 9,6 & 8,0 \\
\hline \multicolumn{3}{|c|}{ Average monthly nominal salary, euro } \\
\hline 161 & 803 & 831 \\
\hline \multicolumn{3}{|c|}{ Students of higher education establishments per 10 thousand population } \\
\hline 493 & 240 & 395 \\
\hline
\end{tabular}

There is shortage of information on the scopes of unofficial trade commonly practiced in Ukraine, especially with neighboring countries with EU membership. Also, there is shortage of information about the amount and structure of expenditures (not recorded in custom documents) by Ukrainians abroad and foreigners in Ukraine, purpose of visit, implications of phenomena and processes related with cross-border movement. The Polish experience shows that statistical data in this field are focused on the needs of central and local administration bodies in border regions, for national and regional policy development [5].
In 2017, the State Statistics Service, the Chief Statistics Department of Poland (Warsaw), the Statistics Department (Rzeszów), the Chief Statistics Department in Lviv regions, the National Academy of Statistics, Accounting and Audit (Kyiv), the Department for Statistics of the Lviv Franko National University implemented the collaborative project "Application of Several Research Methods by Case of Comprehensive Studies of Travels", which objective was to transfer competencies and experiences of Polish statistics on application of several research methods by case of comprehensive studies of travels, production of methodologically consistent data on 
macro-level (for purposes of travel statistics, national accounts, payment balance), meso-level (regional and border areas) and micro-level (for local administration bodies, enterprises and other institutions) and monitoring of socio-economic phenomena in border regions.

Such studies are part of the actions envisaged, above all, by "Strategy of the Development of Official Statisticsin Ukrainefor 2017", "Strategy of Sustainable Development till 2020", being in conformity with the Association Agreement between Ukraine and EU. The reform of the regional development system is a priority of the Strategy of the Development of Ukraine. Its objectives include bridging the gap between regions. The above mentioned actions cannot be implemented without adequate and consistent data about individual regions.

The main priorities of the external policy of Ukraine are processes involved in Ukraine's integration in Europe. They determine the need for intensified mutual relations between Ukraine and neighboring countries, Poland especially. The short distance cross-border movement is a means of the simplified border crossing for residents of both countries, living in the border zone, allowing for regular border crossings by residents of the border zone without visas, for staying in the border zone of the other country. These travels may have social, cultural, family or other justified reasons (not related with profit-making activities).

In the context of newly signed international agreements, in particular the agreement between the Government of the Polish Republic and the Cabinet of Ministers of Ukraine on small distance cross-border movement, the Polish statistics office renewed the study of the circulation of goods and services in this movement in 2008 [6]. Adapted to new conditions and needs, this study involved checks and modifications of the existing methodology.

The methodology includes a study of the circulation of goods and services in cross-border transport corridors by questioning of persons crossing the Polish-Ukrainian border, who are foreigners (with permanent residence abroad) and Poles (who are permanent residents of Poland), and who come back to a resident country from Ukraine.

The questioning of persons crossing the border in border crossings covers the crossings by car, motorcycle, on foot and by train. The persons crossing the border on foot include cyclists and persons using wheelchairs.

The study covers the expenditures of foreigners in Poland and Poles in other countries for purchases of goods, as well as other expenditures, including gastronomic services. The questioning includes the expenditures for purchases of goods not recorded in custom documents.
The study of the circulation of goods and services in cross-border movement is conducted by a representative method enabling to generalize the obtained data for the total number of persons crossing the Polish-Ukrainian border.

The two-stage sampling scheme is used, to include the elements from two stages. First, the random method is used to define two weeks when the questioning will be conducted, after that the period of the day is defined (three hours, i. e. the quarter of 12 hours), corresponding with the work shift of cross border officers. The study is to be conducted for Ukrainians and Poles crossing the border at all the border crossings at the same time. When a person refuses to respond, another person will be questioned. The questioning is conducted on quarterly basis, in randomly selected days of the week, in order to smooth out the data collected in weekends and holidays.

The data are generalized separately for Poles and Ukrainians. The results for provinces are calculated from the results of all the strata.

The current specifics of cross-border mobility of the residents of Carpaty region give clear evidence of large risks of socio-demographic, economic and cultural and moral origin. Given the increasing destructive effects of cross-border mobility, the need for socio-economic protection of persons exposed to the risks of loss of the labor capacity due to its underuse and impossibility for professional development, moral and ethical losses resulting from the forced engagement in illegal means of trade and adaptation of alien behavioral patterns becomes a subject of greater importance.

In view of the above analysis, priority measures to enhance the effectiveness of cross-border labor migration processes in Ukraine should be as follows:

1. The adequate attention paid by central power bodies to the cross-border labor migration processes and their regulation in legal acts.

2. Organize collection and analysis of sound statistical data on real scales of labor migration in Ukraine and cross-border labor migration to neighboring countries; most part of these data should be freely available.

3. Elaborate a single approach to the methodology of migration statistics, because ad hoc sample surveys conducted by non-government and international organizations are, by far and large, irregular and methodologically inconsistent, which does not allow for determining trends or making comparisons; also, results of these surveys do not contain data about labor migrants from border regions.

4. Create collaborative entities in labor markets of border regions, which would simplify job placement procedures in border regions, keep statistical records of cross-border labor migrants, investigate the processes at labor markets of border regions in order to have comprehensive grasp of migration trends. 
6. Improve infrastructures on the border with EU countries, in order to decrease the duration of border crossings and eliminate the threat of emigration of a shuttle migrant to a permanent location of residence from a cross-border region [7].

Also, there is a need for further scientific justification of the applications of instruments for the development of border towns in Ukraine in various aspects of social life. It refers to measures for economic diversification, labor market development and stimulation of business in border towns, which will help reduce the unemployment and minimize the related social tensions [8]. A useful step in this context would be elaboration and implementation of advanced organizational and legal mechanisms for stimulating labor migrant's investment in business development (including credit and consumer cooperation, transactions with bonds etc.).
The statistics of cross-border regions has to face the following challenges:

- improve the comparability of statistical indicators by harmonizing statistical surveys' methodology, terminology, definitions and classifications; activities;

- expand and improve printing and publishing

- develop analytical work;

- introduce and develop cross-border surveys;

- construct on-line cross-border database.

The destructive monofunctionality of small border towns can be replaced by the diversified economic structure by setting up new economic priorities ("growth points"), providing support to competitive business areas and creating effective innovative forms of business organization. This process requires further scientific research and analysis.

\section{Список використаних джерел}

1. Official website The European Commission. URL: https://ec.europa.eu

2. Про транскордонне співробітництво: Закон України від 24.06.2004 р. № 1861-IV, станом на 02.12.2012 p. URL: http://zakon5.rada.gov.ua/laws/show/1861-15

3. Офіційний сайт Головного управління статистики у Львівській області. URL: http://www. lv.ukrstat.gov.ua/

4. Мікула Н. А., Засадко В. В. Транскордонне співробітництво України в контексті євроінтеграції: монографія. Київ: НІСД, 2014. 316 с.

5. Cierpia -Wolan M. Cross-Border Surveys - Some Methodological Aspects // Statistics In Transition. New Series. 2008. Vol. 9, № 2. P. 361-366.

6. Угода між Кабінетом Міністрів України та Урядом Республіки Польща про правила місцевого прикордонного руху: затверджена Постановою Кабінету Міністрів України від 28.03.2008 р. № 139, станом на 17.12.2014 p. URL: http://zakon2.rada.gov.ua/laws/show/616_138

7. Левицька О. Розвиток міграційних процесів у прикордонних регіонах: сучасні виклики та шляхи реагування // Соціально-економічний потенціал транскордонного співробітництва: матеріали Міжнар. наук.-практ. конф. Львів: ЛНУ імені Івана Франка, 2016. С. 18-22.

8. Oleński J. Statistical parainformation platform - foundation of information transparency in heterogeneous international environment (with special reference to the Eastern Partnership initiative) // Proceeding of the International Conference Development of the European Statistical System from the Eastern Partnership perspective - directions and strategy, Krakow, 18-20 October, 2011. Kracow: Central Statistical Office, 2011.

\section{References}

1. Official website of The European Commission. ec.europa.eu. Retrieved from https://ec.europa.eu [in Ukrainian].

2. Zakon Ukrainy “Pro transkordonne spivrobitnytstvo" vid 24.06.2004 r. № 1861-IV, stanom na 02.12.2012 r. [The Law of Ukraine “On Cross-Border Cooperation" of June 24, 2004, № 1861-IV as of December 24. 2012]. zakon5.rada.gov.ua. Retrieved from http://zakon5.rada.gov.ua/laws/show/1861-15 [in Ukrainian].

3. Ofitsiinyi sait Holovnoho upravlinnia statystyky u Lvivskii oblasti [The official website of the Chief Statistics Department in Lviv regions]. wrwo.lv.ukrstat.gov.ua. Retrieved from http://www.lv.ukrstat.gov.ua/ [in Ukrainian].

4. Mikula N. A., \& Zasadko V. V. (2014). Transkordonne spivrobitnytstvo Ukrainy v konteksti yevrointehratsii [Cross-border Cooperation of Ukraine in the Context of Eurointegration]. Kyiv: NISD [in Ukrainian].

5. Cierpiał-Wolan, M. (2008). Cross-Border Surveys - Some Methodological Aspects. Statistic In Transition. New Series, 9 (2), 361-366 [in English].

6. Uhoda mizh Kabinetom Ministriv Ukrainy ta Uriadom Respubliky Polshcha pro pravyla mistsevoho prykordonnoho rukhu: zatverdzhena Postanovoiu Kabinetu Ministriv Ukrainy vid 28.03.2008 r. № 139, stanom na 17.12.2014 r. [The Agreement between the Cabinet of Ministers of Ukraine and the Government of the Republic of Poland on the Rules of Local Cross-Border Movement: Approved by the Resolution of the 
Cabinet of Ministers of Ukraine of March 28, 2008, № 139, as of 17.12.2014]. zakon2.rada.gov.ua. Retrieved from http://zakon2.rada.gov.ua/laws/show/616_138 [in Ukrainian].

7. Levytska O. (2016). Rozvytok mihratsiinykh protsesiv u prykordonnykh rehionakh: suchasni vyklyky ta shliakhy reahuvannia [The Development of Migration Processes in Border Regions: Contemporary Challenges and Ways of Response]. Proceedings from Sotsialno-ekonomichnyi potentsial transkordonnoho spivrobitnytstva [The Socio-economic Potential of Cross-border Cooperation]: Mizhnarodna naukovopraktychna konferentsia - International Scientific and Sractical Conference (pp. 18-22). Lviv: Lviv Franko National University [in Ukrainian].

8. Oleński, J. (2011). Statistical parainformation platform - foundation of information transparency in heterogeneous international environment (with special reference to the Eastern Partnership initiative). Proceedings of the International Conference Development of the European Statistical System from the Eastern Partnership perspective - directions and strategy (October 18-20,2011). Krakow: Central Statistical Office [in English].

\section{О. М. Мотузка}

кандидат економічних наук,

доцент кафедри управління зовнішньоекономічною діяльністю,

E-mail: lemot@i.ua;

\section{В. В. Пархоменко,}

кандидат економічних наук, доцент,

доцент кафедри економіки та бізнесу,

E-mail: pviktoria@ukr.net;

Національна академія статистики, обліку та аудиту

\section{Соціально-економічний розвиток транскордонних територій: статистичний моніторинг}

Методологія дослідження розвитку транскордонних територій є ще мало розвинутою в українській науці, тому пропоноване дослідження передбачає розкриття її сутності, обгрунтування необхідності статистичного моніторингу розвитку транскордонних територій та виявлення прикладних проблем його реалізації на інституційному та регіональному рівнях.

В умовах глобальної ринкової конкуренції ефективний соціально-економічний розвиток транскордонних територій неможливий без формування сприятливого фінансового, інституційного та інфраструктурного середовища. Соціально-економічний розвиток транскордонних територій визначається низкою показників, які відображають можливості територій, розташованих по обидва боки кордону, виробляти певну кількість товарів і послуг, використовуючи при цьому наявні людські та матеріальні ресурси.

3 поглибленням транскордонного співробітництва важливого значення набуває таке поняття, як транскордонна статистика. Транскордонна статистика - це узагальнююча інформація про соціальноекономічний розвиток транскордонних територій, яка повинна слугувати органам державного управління, а також місцевим органам влади та приватним структурам прикордонних регіонів для здійснення транскордонного співробітництва, розвитку партнерських ділових зв'язків, а також для потреб громадськості прикордонних територій.

Джерелом даних транскордонної статистики є регіональна статистика прикордонних територій. Аналіз показав, що методологічні напрацювання, які наразі використовуються в українській статистичній системі для тестування прикордонних районів, у статистиці туризму, зокрема подорожей за кордоном, $€$ недостатніми в контексті інформаційних потреб політики регіонального розвитку, а також у сфері зовнішньої торгівлі, внутрішньої і зовнішньої міграції тощо.

У статистиці транскордонних регіонів потребують вирішення такі питання: 1) покращення порівнянності статистичних показників шляхом гармонізації методології статистичних спостережень, термінів, дефініцій та класифікацій; 2) розширення й удосконалення публікаційної діяльності; 3) розвиток аналітичної роботи; 4) упровадження та розвиток транскордонних спостережень; 5) створення транскордонної бази даних в оn-line доступі.

Ключові слова: сочіально-економічний розвиток, мобільність, моніторинг, транскордонне співробітництво, транскордонні території, сусідні країни. 


\section{Е. Н. Мотузка,}

кандидат экономических наук,

доцент кафедры управления внешнеэкономической деятельностью,

E-mail: lemot@i.ua;

В. В. Пархоменко,

кандидат экономических наук, доцент,

доцент кафедры экономики и бизнеса,

E-mail: pviktoria@ukr.net;

Национальная академия статистики, учета и аудита

\section{Социально-экономическое развитие трансграничных территорий: статистический мониторинг}

Исследованы проблемы, возникающие в процессе развития трансграничных территорий. Обоснована необходимость развития методологии исследования трансграничных территорий. Рассмотрено понятие "трансграничная статистика" и освещены сферы ее использования. Сформулированы ключевые задачи улучшения трансграничного сотрудничества и использования инструментов развития приграничных городов.

Ключевые слова: социально-экономическое развитие, мобильность, мониторинг, трансграничное сотрудничество, трансграничные территории, соседние страны.

Bibliographic description for quoting:

Motuzka, O. M., \& Parkhomenko, V. V. (2018). The Socio-Economic Development of Cross-Border Territories: Statistical Monitoring. Statystyka Ukrainy - Statistics of Ukraine, 1, 61 -67 [in English].

Бібліографічний опис для цитування:

Мотузка О. М., Пархоменко В. В. Соціально-економічний розвиток транскордонних територій: статистичний моніторинг (публікується англійською мовою) // Статистика України. 2018. № 1. С. 61-67. 